\title{
The economics of water buffalo (Bubalus bubalis) breeding, rearing and direct marketing
}

\author{
Weert Sweers' ${ }^{1}$, Thomas Möhring² and Jürgen Müller ${ }^{1}$ \\ 'Working Group Grassland and Forage Science, Faculty of Agricultural and Environmental Sciences, University of \\ Rostock, Rostock, Germany, ${ }^{2}$ Landscape preservation farm »Gut Darß«, Born, Germany
}

\begin{abstract}
The aim of this study was to analyse the economic feasibility of water buffalo rearing under rough wet grassland conditions in Germany. Our analysis was based mainly on data from one of Germany's largest water buffalo herds, which was kept by the landscape preservation farm "Gut Darß«. To check a variety of cost-benefit constellations, we conducted a Monte Carlo simulation. The overall rearing costs per cow totalled $1039 € \mathrm{a}^{-1}$. The direct marketing yields per bull ranged from $3797 €$ to $5298 €$. The costs of direct marketing were not generally taken into account because of the high degree of variation and specificity of this position. Reproductive performance, e.g. calf-to-calf interval, was found to have the highest impact on overall economic performance. Our results suggest that water buffalo rearing in Germany has the potential to be economically feasible, at least if direct marketing. Additionally, we conclude that reproductive performance has a major impact on the feasibility of the production system which, in turn, has consequences for breeding concepts.
\end{abstract}

Keywords: water buffalo, breeding strategies, grazing economy, contribution margin method

Abbreviations: CTC: calf-to-calf interval

Archiv Tierzucht 57 (2014) 22, 1-11

doi: 10.7482/0003-9438-57-022
Received: 28 November 2014 Accepted: 6 June 2014 Online: 5 August 2014

\section{Corresponding author:}

Weert Sweers; email: weert.sweers@uni-rostock.de

Working Group Grassland and Forage Science, Faculty of Agricultural and Environmental Sciences, University of Rostock, Justus-von-Liebig-Weg 6, 18059 Rostock, Germany

() 2014 by the authors; licensee Leibniz Institute for Farm Animal Biology (FBN), Dummerstorf, Germany. This is an Open Access article distributed under the terms and conditions of the Creative Commons Attribution 3.0 License (http://creativecommons.org/licenses/by/3.0/). 


\section{Introduction}

The area of restored wetlands and rewetted grasslands in Germany has increased in recent years and looks set to increase further as climate protection goals are pursued (Ullrich \& Riecken 2012). Since, in most cases, there is a need for ongoing management concepts to maintain the habitat function of wetlands once they have been restored (Ostermann 1998), a number of wetland management tools have been developed, mainly for nature conservation purposes (Middleton et al. 2006). One of these tools is wetland grazing, which is especially common in Europe (Middleton et al. 2006). However, rewetted grasslands do not always seem to be suitable for common beef cattle breeds (Limousin, Charolais), for a variety of reasons. The vegetation of restored wetlands is often of poor forage quality (Bockholt \& Buske 1997), and grazing can be limited by nature conservation restrictions (Bokdam \& Wallis de Vries 1992). Additionally, problems with poaching (Scholz \& Hennings 1995) and the avoidance by beef cattle of certain wetland plants (Köster et al. 2004) have also been reported. As a solution to these problems, several authors in Germany have recently suggested that water buffaloes may be more suited to wetland grazing (Enge 2009, Sweers et al. 2013b, Wichtmann 2011, Wiegleb \& Krawczynski 2010). Water buffaloes are successfully used for beef production in rough wet grasslands in Brazil (Bernardes 2007, Ohly \& Hund 2000), Australia (Lemcke 2006), Greece (Georgoudis et al. 1999) and, on a very small scale, in Germany (Sweers et al. 2013a). The idea of introducing them as a grazing animal to mid-European wetlands during the vegetation seasons seems, therefore, to be obvious.

Water buffalo breeding in Germany has, until recently, been little more than a hobby, but interest in it is now starting to grow (Spindler 2008). One point which stands in the way of the serious establishment of water buffalo breeding in Germany is the limited marketability of its main product, weaned calves. At present, water buffalo beef can only be sold via direct, farmer-to-consumer marketing (Spindler 2008), which increases the costs of investment in the production system and makes it unsuitable for normal mixed farms whose main business lies in cash cropping.

The development of a production system for breeding water buffalo for landscape preservation purposes is in its initial stages in Germany. However, a growing demand for information regarding water buffalo rearing has recently become detectable (Antkowiak et al. 2012). Before farmers invest in any potential production system, however, its economic sustainability needs to be analysed under standardized conditions.

The main factors influencing economic sustainability are:

- animal performance

- the cost structure of the rearing system

- sales profit.

Furthermore, knowledge of the specific economics of different animal husbandry systems is crucial when planning breeding strategies and weighing up specific breeding traits, as has been shown by Visscher et al. (1994) for pasture-based dairying and Groen (1989) and Amer et al. (2001) for beef cattle production systems. Comparable results for pasture-based water buffalo rearing systems are not available, despite growing interest in the socio-economic data necessary to adjust breeding goals to current consumer demands for animal products (Nielsen et al. 2011). 
We investigated production data pertaining to one of Germany's largest water buffalo herds in order to analyse i) the framework within which water buffalo breeding could be economically feasible under local/German conditions ii) the production factors with the main influence on economic success and iii) the consequences of i) and ii) for the development of breeding strategies.

\section{Material and methods}

The focus of the analysis was the profitability of the production system and its economical robustness. The method used to analyse the cost structure of the system was standard German Contribution margin method »Deckungsbeitragsrechnung (Anonymous 2011) which considers the costs and yields linked to active production, and the variable costs.

The fixed costs of infrastructure (depreciation of livestock buildings; refrigeration system) were only taken into account where they could definitely be assigned to the production system associated with water buffalo rearing. Our calculations end at the level of direct marketing because the sheer number of options here makes the itemization of these costs very difficult and any attempt to do so may be more misleading than constructive.

In order to test the probability of different cost-benefit constellations, we carried out a Monte Carlo simulation, a common method for analysing pasture-based production systems (Evans et al. 2007, Werth et al. 1991). In this stochastic simulation, multiple input values can be varied simultaneously within a prescribed range and a prescribed probability. A triangular probability distribution defined by the maximum, minimum and mode values (mode value $=$ value with the highest probability) was applied for each of the input values used.

The Monte Carlo simulation was based on the following formula, with

calf per year $(c p y)=0.5 \times$ produced calf per cow and year

(based on calf-to-calf interval)

Contribution margin $€$ cow $^{-1}=([c p y-$ calves lost $] \times$ price of beef $)+$

([cpy - calves lost] $\times$ price of heifer) - costs(each $\times$ cpy \pm range $)$

The data base used for the analysis was made up of production data pertaining to the 120 head water buffalo herd kept by the landscape preservation farm »Gut Darß« situated in the north east of Germany. The water buffaloes in question graze on coastal tidal grasslands at stocking rates of nearly 1.3 livestock units per ha to prevent reed encroachment (Sweers et al. 2013a). The grazing season on the wet sites starts in May and ends in October. The calves are mainly born from December to March and are weaned at the age of 10-12 months at a live weight of $360 \mathrm{~kg}$. After this, female calves are kept for reproduction (in order to increase the stock) and male calves are fattened on pasture with supplementary concentrate feeding in winter ( $2 \mathrm{~kg} / \mathrm{d}$ bull) until they are slaughtered for direct marketing at $\sim 36$ months $/ 650 \mathrm{~kg}$. In October, the cows are moved to a winter pasture with free access to an open stable, where they are reared until May. During this period, they are fed on pasture, hay and small amounts of concentrate $(200 \mathrm{~g} / \mathrm{d}$ cow $)$. 
Data regarding feeding costs, reproductive performance and direct marketing yields were collected on the Gut Darß farm. Data from two other buffalo farms in Germany (Beuerbach, Baden-Württemberg and Spreeaue, Brandenburg) helped to ensure that the price range reflected the actual market situation. We also took standard values (Dietze \& Heilmann 2010, Spindler 2008) into consideration to make the results as transferable as possible to other farms.

\section{Results}

The costs of rearing a water buffalo cow amount to $1039 € \operatorname{cow}^{-1} \mathrm{a}^{-1}$. The costs of rearing a heifer ( $435 \mathrm{~d}$ until hypothetical sale) amount to $791 €$ heifer $^{-1}$, and the costs of rearing a bull (615 d until slaughter at $650 \mathrm{~kg}$ live weight) amount to $1103 €$ bull $^{-1}$ (Table 1). The bulk of the costs are forage costs (winter forage, summer forage, concentrate) at $268 € \operatorname{cow}^{-1} \mathrm{a}^{-1}, 316 €$ heifer $^{-1}$ and $486 €$ bull- $^{-1}$ (Table 1). Another major cost is bedding at $120 € \operatorname{cow}^{-1} \mathrm{a}^{-1}, 143 €$ heifer $^{1}$ and $203 €$ bull $^{-1}$ (Table 1). The cost of labour amounts to $233 € \operatorname{cow}^{-1} \mathrm{a}^{-1}, 83 €$ heifer $^{-1}$ and $117 €$ bull $^{-1}$ (Table 1). Also significant are the costs of interest on stock capital, which amount to $138 €$ cow $^{-1} \mathrm{a}^{-1}, 100 €$ heifer $^{-1}$ and $86 €$ bull $^{-1}$ (Table 1).

Table 1

Cost analysis of water buffalo rearing on the farm »Gut Darß« Range of values based on Dietze \& Heilmann 2010 and expert knowledge of »Gut Darß«

\begin{tabular}{|c|c|c|c|c|c|}
\hline Costs & $€ \operatorname{cow}^{-1} a^{-1}$ & $\begin{array}{c}€ \text { heifer }^{1} \\
435 \mathrm{~d}\end{array}$ & $\begin{array}{l}€ \text { bull }^{-1} \\
615 d\end{array}$ & Data origin & Range \\
\hline \multicolumn{6}{|l|}{ Variable costs } \\
\hline Winter forage & 148 & 204 & 296 & Own survey & $\pm 25 \%$ \\
\hline Summer forage & 112 & 112 & 152 & Own survey & $\pm 25 \%$ \\
\hline Concentrate & 8 & - & 38 & Own survey & $\pm 25 \%$ \\
\hline $\begin{array}{l}\text { Mineral } \\
\text { supplementation }\end{array}$ & 4 & 4 & 4 & Spindler (2008) & $\pm 10 \%$ \\
\hline Bedding & 120 & 143 & 203 & Own survey & $\pm 25 \%$ \\
\hline Water & 26 & 31 & 44 & Spindler (2008) & $\pm 5 \%$ \\
\hline Veterinary & 20 & 23 & 33 & Spindler (2008) & $\pm 10 \%$ \\
\hline Insurance, dues & 30 & 36 & 50 & Spindler (2008) & no range \\
\hline $\begin{array}{l}\text { Interest on working } \\
\text { capital }\end{array}$ & 18 & 22 & 33 & Own survey & no range \\
\hline Interest on stock capital & 138 & 100 & 86 & Own survey & no range \\
\hline Machine costs & 28 & 33 & 47 & Spindler (2008) & $\pm 20 \%$ \\
\hline Labour & 233 & 83 & 117 & Own survey & $\pm 25 \%$ \\
\hline $\begin{array}{l}\text { Slaughter and } \\
\text { butchering }\end{array}$ & & & 100 & & \\
\hline Total & 1039 & 791 & 1103 & & \\
\hline Stable & 52 & & & Spindler (2008) modified & \\
\hline Refrigeration system & 102 & & & Spindler (2008) modified & \\
\hline
\end{tabular}


The direct marketing yields from one water buffalo bull carcass vary widely between the three farms.

Table 2

Direct marketing yields from one water buffalo bull carcass on three different farms

\begin{tabular}{lrrrrrrr}
\hline Cut of meat & Weight & \multicolumn{2}{c}{ Beuerbach } & \multicolumn{2}{c}{ Gut Darß } & \multicolumn{2}{c}{ Spreeaue $^{2}$} \\
& \multicolumn{1}{c}{$\mathrm{kg}$} & \multicolumn{1}{c}{$€ \mathrm{~kg}^{-1}$} & $€$ Bull- $^{-1}$ & $€ \mathrm{~kg}^{-1}$ & $€$ Bull $^{-1}$ & $\mathrm{Ekg}^{-1}$ & $€$ Bull- $^{-1}$ \\
\hline Tenderloin & 5.00 & 50.22 & 251.10 & 65.01 & 325.05 & 48.26 & 241.30 \\
Rib \& sirloin & 5.80 & 41.66 & 269.17 & 46.41 & 269.17 & 34.40 & 199.52 \\
Rump steak & 11.50 & 41.66 & 479.09 & 46.41 & 533.71 & 27.80 & 319.70 \\
Silverside & 7.90 & 35.80 & 282.82 & 33.39 & 263.78 & 25.01 & 197.57 \\
Thick flank & 52.00 & 31.43 & 1634.36 & 27.81 & 1446.12 & 22.32 & 1160.64 \\
Stewing meat & 24.50 & 31.43 & 770.03 & 27.81 & 681.34 & 20.36 & 498.82 \\
Topside & 5.00 & 36.17 & 180.85 & 23.23 & 116.15 & 21.39 & 106.95 \\
Meat for soup & 52.00 & 16.36 & 850.72 & 11.14 & 579.28 & 9.48 & 492.96 \\
Meat for mincemeat & 116.00 & 5.00 & 580.00 & 5.00 & 580.00 & 5.00 & 580.00 \\
Total & 280.00 & & 5298.14 & & 4794.60 & & 3797.46 \\
\hline
\end{tabular}

${ }^{1}$ modified Anonymous (2013a) Beuerbach, ${ }^{2}$ modified Anonymous (2013b) Spreeaue

The highest direct marketing yield is achieved by the farm Beuerbach in southern Germany at $5298 €$ per bull (Table 2). The farm on which this study focuses, »Gut Darß«, is able to obtain a direct marketing yield of $4794 €$, which is about $1000 €$ higher than that achieved by the farm Spreeaue (Table 2).

The Monte Carlo simulation was based on the values from Table 1 and the economic assumptions listed in Table 3.

Table 3

Economic assumptions for Monte Carlo simulation

\begin{tabular}{lcrrrc}
\hline Yields & Unit & Max & Mode & Min & Data origin \\
\hline Price of meat (bull) & $€$ & 5298 & 4794 & 3797 & Beuerbach / Gut Darß / Spreeaue \\
$\begin{array}{l}\text { Price of heifer } \\
\text { Calf-to-calf interval }\end{array}$ & $€$ & 3000 & 2500 & 1500 & $\begin{array}{c}\text { Expert Knowledge } \\
\text { (Dobson \& Kamonpatana 1986, } \\
\text { Calf losses }\end{array}$ \\
\hline
\end{tabular}

Total costs determined by Monte Carlo simulation ranged from $785 € \operatorname{cow}^{-1} \mathrm{a}^{-1}$ to $1577 \mathrm{cow}^{-1}$ $\mathrm{a}^{-1}$ (including costs per output), depending on cpy-quotient. The overall yield (bull and heifer) ranged from $1336 \operatorname{cow}^{-1} a^{-1}$ up to $3116 \operatorname{cow}^{-1} a^{-1}$.

Simulation. Mean is $744.34 € \operatorname{cow}^{-1} \mathrm{a}^{-1}$, with a $90 \%$ probability range from $234.56 € \operatorname{cow}^{-1} \mathrm{a}^{-1}$ to $1237.33 € \operatorname{cow}^{-1} a^{-1}$, and a 5 percent probability above or below.

Every column in this diagram stands for the probability of a contribution margin result occurring. The Monte Carlo simulation shows that there is a $99 \%$ probability of a contribution 


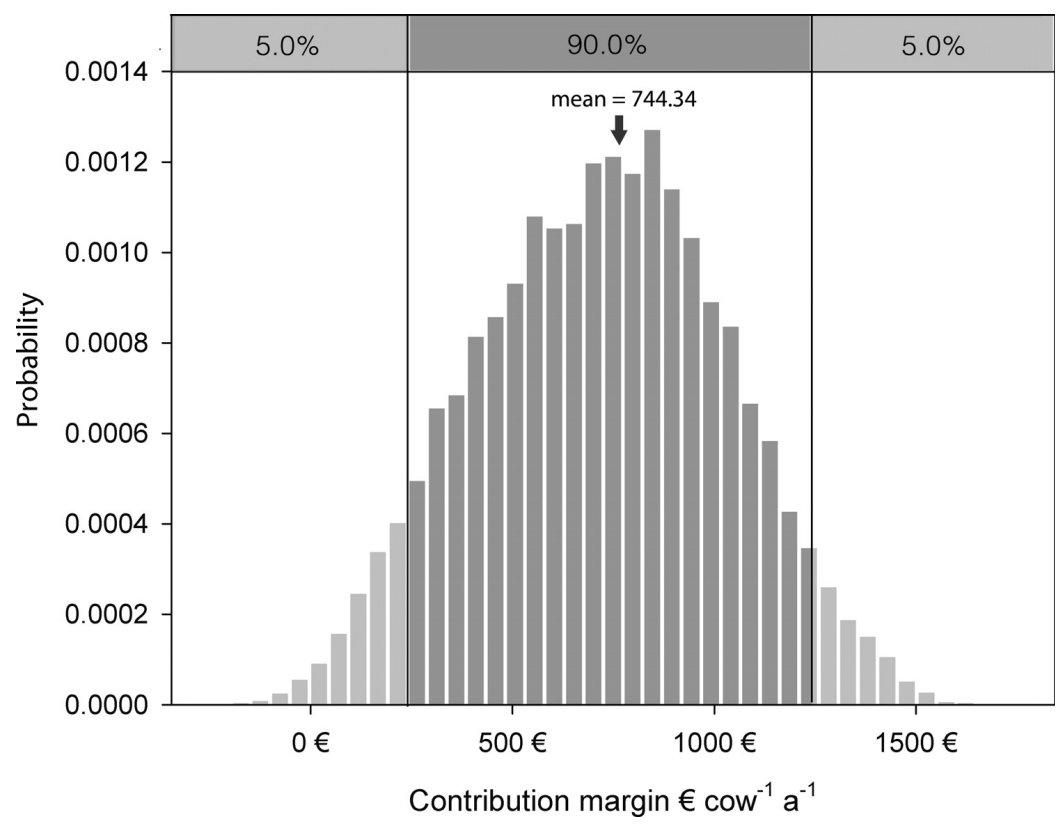

Figure 1: Probability of contribution margin results from Monte Carlo

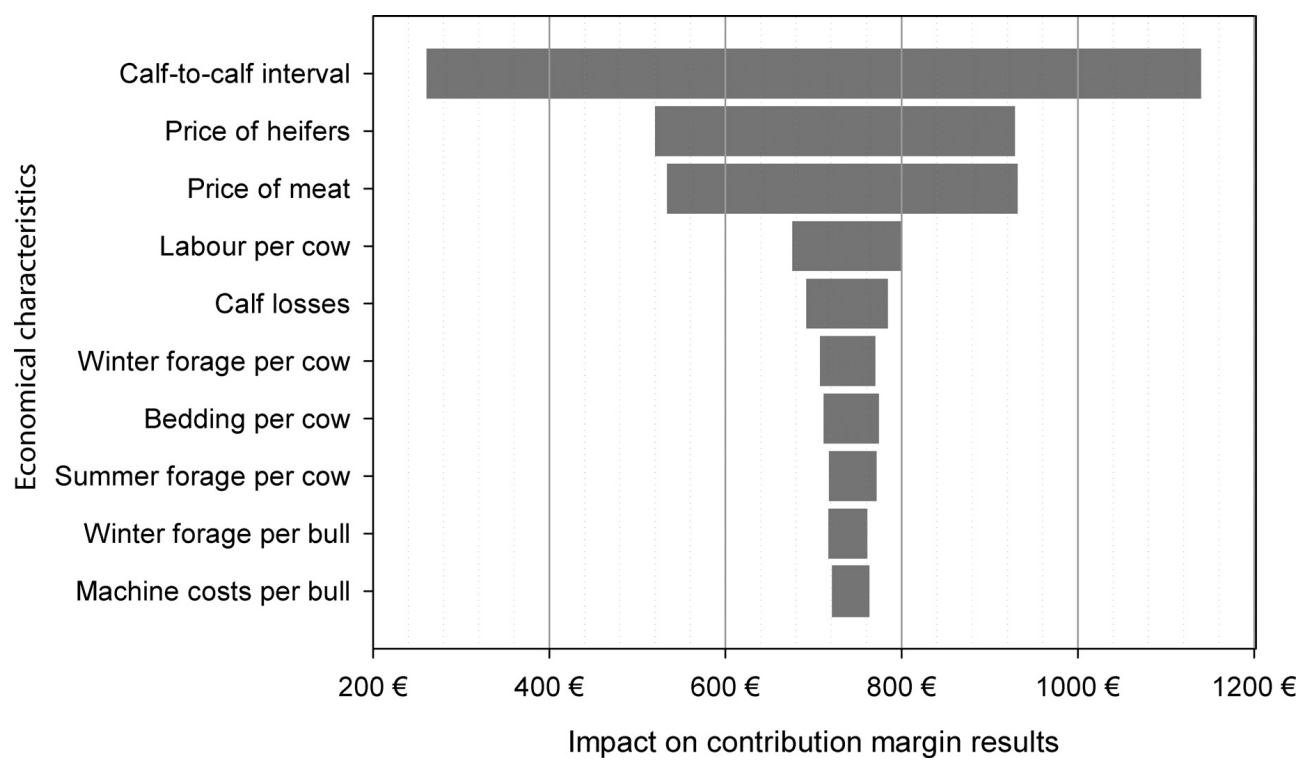

Figure 2: Impact of most influential characteristics of the buffalo rearing procedure on contribution margin results from Monte Carlo simulation (impact in $€$ as grey bar) 
margin result within a positive range. There is a $90 \%$ probability of a contribution margin between $235 €$ and $1237 €$ (Figure 1). The mean contribution margin is $744 €$ (Figure 1).

Each bar is obtained by considering one input and ignoring everything else but the output. The procedural characteristic with the greatest impact on contribution margin results is calf-to-calf interval, because this defines the output of the production system (Figure 2). In second and third place, respectively, the prices of heifers and meat also have an important impact on economic results (Figure 2).

\section{Discussion}

\section{Cost analysis}

The first part of our investigation was a cost analysis of the production system water buffalo rearing. The overall costs are comparable to those reported by Dietze \& Heilmann (2010) for suckling cow production systems in Mecklenburg-Western Pomerania. This was expected because the rearing conditions are similar (Sweers et al. 2013a). To increase the profitability of the production system, the first move would usually be to reduce costs. At this point, however, it is important to discuss the degree to which a cost reduction is possible and reasonable. The costs of summer forage are hard to reduce, because water buffaloes graze on very extensively managed pastures where fertilization and sward renewal are excluded. E-fencing as a further variable cost is essential and cannot be avoided. There is very little potential for savings when it comes to the costs of winter forage since the production of hay is economically optimised and meadow leasing inexpensive. Cutting down expenditure on the forage conservation process commonly results in lower winter forage quality. When evaluating the feeding of water buffalo cows, we need to keep in mind that a poor forage supply (quantity and especially quality) may lead to a decline in reproductive performance (Perera 2011). The impact of poor reproductive performance on the economic results will be discussed later on. Reducing concentrate use during the fattening phase of the bulls is one aspect that could be debated, though there is also the option of shortening the fattening phase by intensifying feeding and thus reducing overall costs. The intensive fattening of water buffaloes has already been successfully tested by Charles \& Johnson (1975), Valin et al. (1984) and Gandra et al. (2011). However, this feeding concept is not particularly compatible with the discontinuous nature of farmer to consumer direct marketing. At first glance, there may be saving potential when it comes to bedding, which makes up a considerable proportion of the overall costs (Table 1). However, EU guidelines on organic agriculture prescribe the use of bedding material (European Commission 1999) and constructing a slatted floor system would be a high investment cost. The following cost positions (mineral supplementation; water; veterinary; insurance, dues; interest on working capital; interest on stock capital; machine costs) are either minimum requirements for standard animal husbandry, or unavoidable and therefore unworthy of discussion. Ultimately, labour costs may be the most suitable position for reduction because they lay in this study above those reported by Dietze \& Heilmann (2010). 


\section{Direct marketing yields}

Table 2 illustrates that the price of water buffalo meat varies widely. This is definitely down on the one hand to the sales and marketing skills of individual farms, but also attributable to purchasing power in the regions in question (Werner et al. 2006). At the Gut Darß the price for certain pieces of water buffalo meat is in average $25 \%$ higher than those of other organic beef cattle. The high overall price level obtained for water buffalo meat is due to its reputation for superior quality and taste (Golze 2007). Nevertheless, only a slight difference in meat quality was detected by Joksimovic \& Ognjanovic (1977), Valin et al. (1984) and Lapitan et al. (2008). In South America the price for water buffalo meat is even only slightly higher than the price of beef from cattle (Vaz et al. 2012). Forfeiting its exclusive status in the future in combination with a growing supply might lead to the decrease of prices.

Moreover, it becomes clear that while the premium cuts (tenderloin, rump steak etc.) can be sold at very high prices, there are not many of them to be had of per bull. The marketability of the remaining cuts is therefore also important for sales revenue.

\section{Simulation of the production system}

As figure 1 demonstrates, there is a $99 \%$ probability of contribution margins lying within a positive range. This does not mean that the production system is lucrative, however. The fixed costs and the costs of farmer to consumer direct marketing still have to be paid from this sum, and an additional $10 \%$ should ideally be generated as entrepreneurial profit. But with the mean contribution margin of $744 € \operatorname{cow}^{-1} \mathrm{a}^{-1}$, a predictable parameter now exists. The contribution margin will be determined by the amount of water buffalo meat obtained, and this varies according to the calf-to-calf interval (CTC) (CTC $730 \mathrm{~d}=70 \mathrm{~kg}$; CTC $365 \mathrm{~d}=140 \mathrm{~kg}$ $\left.\operatorname{cow}^{-1} \mathrm{a}^{-1}\right)$. This parameter enables us to calculate the optimum herd size for the specific direct marketing structures, which are characterized by a limited quantitative demand of water buffalo beef.

The factors shown in Figure 2 to impact contribution margins per $\operatorname{cow}^{-1} \mathrm{a}^{-1}$ demonstrate that reproductive management has a major effect on the profitability of the production system. The CTC has the highest impact on the contribution margin per $\operatorname{cow}^{-1} \mathrm{a}^{-1}$. Maintaining a high level of reproductive management requires some effort and certain measures, which may preclude cost reduction in other areas. One example is forage and mineral supply (Perera 2011). Moreover, the problems of detecting when a water buffalo cow is on heat (Singh et al. 1984) demand intensive observation of the herd (Barile 2005) if the desired (short) CTCs are to be achieved.

The prices of heifers and meat are the second and third most important factors to impact on contribution margins. The price of heifers is based here on a hypothetical monetary calculation, but it can be assumed that heifer prices will develop positively in the future as the area of land with special landscape preservation needs increases (Ullrich \& Riecken 2012). The prices achievable for meat depend on the direct marketing skills of the farms involved. Nevertheless, the trend towards highly priced luxury foodstuffs with special values continues unabated (Thilmany et al. 2006). As mentioned in the cost analysis, the manpower (labour) required makes up a relatively high proportion of the overall costs and therefore has a considerable impact on the contribution margin per $\operatorname{cow}^{-1} \mathrm{a}^{-1}$. 


\section{Consequences for breeding strategies}

Unlike the study by Visscher et al. (1994) into pasture-based dairy production systems, this investigation was not designed to weight individual breeding traits. Nevertheless, some aspects of the 1994 study are worth discussing in the context of buffalo breeding. In general, breeding concepts for water buffalos in Germany are at a pioneer stage and suffer from the limited population size. Expanding the genetic base by means of artificial insemination would seem to be a logical solution, but this practice is foiled by the limited success rate in water buffalos (Lemcke 2008). Kluyts et al. (2003) propose, on the basis of various studies in cattle, that a key measure for optimising breeding strategies is to define selection indices for the main breeding traits that take into account both biological and economic parameters. In our case the superior economic weight of pregnancy traits constitutes a reason to include them in selection schemes, despite their low heritability (Burrow 2001). Concentration on live weight gain as a breeding trait is only constructive if variation in this character on the population level is based on the natural forage supply and not influenced by supplemental feeding.

We were able to confirm in this study that water buffalo rearing for beef production has a high probability of being economically feasible, at least if direct marketing is used. We were also able to highlight the huge impact of reproductive performance on the economic results of this production system. Implementing these findings in breeding schemes, however, is complicated by the reproductive-physiological limits to which water buffalos are subject. Success in enhancing the genetic potential of water buffalos to transform rough wetland vegetation into meat cannot be expected in the short term. The need for specialized landscape preservation (Sweers et al. 2013a) may enhance the feasibility of rearing this specialized domestic animal, when money for nature conservation measures can be attained. Also Holló et al. (2013) report of acceptable meat qualities produced on rough grasslands with water buffaloes. So though management improvements have a higher priority in water buffalo rearing as things currently stand, it is imperative that breeding potential be kept in view.

\section{Acknowledgements}

This work was funded by the German Federal Ministry of Education and Research and is part of the joint project »Vorpommern Initiative Paludiculture« (FKZ 033L030).

\section{References}

Amer PR, Simm G, Keane MG, Diskin MG, Wickham BW (2001) Breeding objectives for beef cattle in Ireland. Livest Prod Sci 67, 223-239

Anonymous (2011) [Farming cost analysis: guidelines for practice]. DLG-Verlag, Frankfurt, Germany [in German]

Anonymous (2013a) [Pricelist for buffalo beef: Beuerbach] http://www.bueffelhof-beuerbach.de/hofladenprodukte.php [last accessed 18.11.2014]

Anonymous (2013b) [Pricelist for buffalo beef: Spreeaue] http://www.agrar-cottbus.de/aueroxen/bestellung/ preislisten.php [last accessed 18.11.2014]

Antkowiak I, Pytlewski J, Purczyńska A, Skrzypek R (2012) A preliminary study of the behaviour of water buffaloes (Bubalus bubalis) imported to Poland (Short Communication). Arch Tierz 55, 415-419 
Barile VL (2005) Reproductive efficiency in female buffaloes. In: Borghese A (ed.) Buffalo Production and Research. FAO, Rome, Italy, 77-108

Bernardes $O$ (2007) Buffaloes breeding in Brasil. Ital J Anim Sci 6 (Suppl.), 162-167

Bockholt R, Buske $F$ (1997) [Forage quality range of fen grassland taking into account the most frequent autochthonal plants]. Das Wirtschaftseigene Futter 43, 5-20 [in German]

Bokdam J, De Vries Wallis MF (1992) Forage Quality as a Limiting Factor for Cattle Grazing in Isolated Dutch Nature Reserves. Conserv Biol 6, 399-408

Burrow HM (2001) Variances and covariances between productive and adaptive traits and temperament in a composite breed of tropical beef cattle. Livest Prod Sci 70, 213-233

Charles DD, Johnson ER (1975) Liveweight gains and carcass composition of buffalo (Bubalus bubalis) steers on four feeding regimes. Aust J Agric Res 26, 407-413

Dietze M, Heilmann H (2010) [The profitability of beef production in Mecklenburg-Western Pomerania]. Research Center for Agriculture and Fisheries, Research No. 1/23, Gülzow, Germany

Dobson H, Kamonpatana M (1986) A review of female cattle reproduction with special reference to a comparison between buffaloes, cows and zebu. J Reprod Fertil 77, 1-36

Enge D (2009) [Landscape Maintenance using Water Buffaloes]. Naturschutz und Landschaftsplanung 41, 277285 [in German]

European Commission (1999) Council Regulation (EC) No 1804/1999 of 19 July 1999 supplementing Regulation (EEC) No 2092/91 on organic production of agricultural products and indications referring thereto on agricultural products and foodstuffs to include livestock production. Official Journal L 222, $1-28$.

Evans JR, Sperow M, D'Souza GE, Rayburn EB (2007) Stochastic Simulation of Pasture-Raised Beef Production Systems and Implications for the Appalachian Cow-Calf Sector. J Sustain Agric 30, 27-51

Gandra JR, Freitas Jr JE, Barletta RV, Maturana Filho M, Gimenes LU, Vilela FG, Baruselli PS, Rennó FP (2011) Productive performance, nutrient digestion and metabolism of Holstein (Bos taurus) and Nellore (Bos taurus indicus) cattle and Mediterranean Buffaloes (Bubalis bubalis) fed with corn-silage based diets. Livest Sci 140, 283-291

Georgoudis AG, Papanastasis VP, Boyazoglu JG (1999) Use of Water Buffalo for Environmental Conservation of Waterland. Asian-Aust J Anim Sci 12, 1324-1331

Golze M (2005) [First performance figures from water buffaloes in Saxony]. Information service for counseling and school of Saxon agricultural administration 12/2004, 81-92 [in German]

Golze M (2007) [Selected results of water buffalo rearing in Germany]. Saxonian Department of Agriculture. Köllitsch, Germany http://www.smul.sachsen.de/lfulg/download/Golze_Bueffelhaltung_in_Deutschland. pdf [last accessed 18.06.2014]

Groen AF (1989) Economic values in cattle breeding. I. Influences of production circumstances in situations without output limitations. Livest Prod Sci 22, 1-16

Holló G, Barna B, Nuernberg K (2013) Characterisation of carcass composition and meat quality of male suckling buffalo calves kept on natural grassland. Arch Tierz 56, 107

Joksimovic J, Ognjanovic A (1977) Comparison of carcase yield, carcase composition and quality characteristics of buffalo meat and beef. Meat Sci 1, 105-110

Kluyts JF, Neser FWC, Bradfield MJ (2003) Development of breeding objectives for beef cattle breeding: derivation of economic values. S Afr J Anim Sci 33, 142-158

Köster T, Kauer K, Tõnutare T, Kõlli R (2004) The management of the coastal grasslands of Estonia. In: Brebbia CA, Saval Perez JM, Garcia Andion L, Villacampa Y (eds.) Coastal Environment V incorporating Oil spill studies. WITpress, Southampton et al., 45-54

Lapitan RM, Del Barrio AN, Katsube O, Ban-Tokuda T, Orden EA, Robles AY, Cruz LC, Kanai Y, Fujihara T (2008) Comparison of carcass and meat characteristics of Brahman grade cattle (Bos indicus) and crossbred water buffalo (Bubalus bubalis) fed on high roughage diet. Anim Sci J 79, 210-217 
Lemcke B (2006) Water Buffalo Farming in Southern Australia. Report of Department of Primary Industry, Fisheries and Mines of the Northern Territory Government. Serial No. 610, Agdex No. 487/20, Darwin, NT, Australia http://www.nt.gov.au/d/Content/File/p/Anim_Man/610.pdf [last accessed 18.06.2014)

Lemcke B (2008) Australian Water Buffalo - Genetic and Reproduction Improvements. Australian Government, Rural Industries Research and Development Corporation, Publication No. 08/189, Canberra, Australia https://rirdc.infoservices.com.au/downloads/08-189 [last accessed 18.06.2014]

Middleton BA, Holsten B, van Diggelen R (2006) Biodiversity management of fens and fen meadows by grazing, cutting and burning. Appl Veg Sci 9, 307-316

Nielsen HM, Olesen I, Navrud S, Kolstad K, Amer P (2011) How to Consider the Value of Farm Animals in Breeding Goals. A Review of Current Status and Future Challenges. J Agric Environ Ethics 24, 309-330

Ohly JJ, Hund M (2000) Floodplain animal husbandry in central Amazonia. In: Junk WJ, Ohly JJ, Piedade MTF, Soares MGM (eds.) The Central Amazon Floodplain: Actual Use and Options for a Sustainable Management. Backhuys Publishers, Leiden, The Netherlands, 313-343

Ostermann OP (1998) The need for management of nature conservation sites designated under Natura 2000. J Appl Ecol 35, 968-973

Perera BMAO (2011) Reproductive cycles of buffalo. Anim Reprod Sci 124, 194-199

Scholz A, Hennings HH (1995) [Bearing capacity for grazing in connection with the rewetting of fens]. Zeitschrift für Kulturtechnik und Landentwicklung 36, 162-164

Singh G, Singh BC, Sharma SS, Sharma RD (1984) Studies on oestrous symptoms of buffalo heifers. Theriogenology 21, 849-858

Spindler B (2008) [Survey of basic and planning data for the rearing of buffalo and water buffalo]. Veterinary University of Hannover [in German] http://www.bueffelhof-heerdes.de/downloads/Bison_und_Bueffel. pdf [last accessed 18.06.2014]

Sweers W, Horn S, Grenzdörffer G, Müller J (2013a) Regulation of reed (Phragmites australis) by water buffalo grazing: use in coastal conservation. Mires and Peat 13: Art. 3. http://mires-and-peat.net/media/map13/ map_13_03.pdf [last accessed 18.06.2014]

Sweers W, Kanswohl N, Müller J (2013b) [How suitable is the water buffalo (Bubalus bubalis) for landscape preservation purposes?] Zuechtungskunde 85, $462-478$ [in German]

Thilmany DD, Umberger WJ, ZiehI AR (2006) Strategic market planning for value-added natural beef products: A cluster analysis of Colorado consumers. Renew Agric Food Syst 21, 192-203

Ullrich K, Riecken U (2012) [Bog and fen conservation strategies, initiatives and programmes in Germany] Natur und Landschaft 87, 81-86 [in German]

Valin C, Pinkas A, Dragnev H, Boikovski S, Polikronov D (1984) Comparative study of buffalo meat and beef. Meat Sci 10, 69-84

Vaz FN, Vaz RZ, Pascoal LL, Restle J, Leal WS, de Ávila MM (2012) Economical Analysis and Commercial Cuts Yields of Buffaloes and Bovines of Both Sexes. J Anim Prod Adv 10, 436-444

Visscher PM, Bowman PJ, Goddard ME (1994) Breeding objectives for pasture based dairy production systems. Livest Prod Sci 40, 123-137

Werner C, Backhaus L, Wicke M (2006) [Direct selling of meat and meat products in Saxony-Anhalt and Lower Saxony: Comparative trial]. Deutsche Lebensmittel-Rundschau 102, 319-325 [in German]

Werth LA, Azzam SM, Nielsen MK, Kinder JE (1991) Use of a simulation model to evaluate the influence of reproductive performance and management decisions on net income in beef production. J Anim Sci 69, 4710-4721

Wichtmann W (2011) Land use options for rewetted peatlands - Biomass use for food and fodder. In: Tanneberger F, Wichtmann W (eds.) Carbon credits from peatland rewetting. Schweizerbart Science Publishers, Stuttgart, Germany, 110-113

Wiegleb G, Krawczynski R (2010) Biodiversity Management by Water Buffalos in Restored Wetlands. Forest Ecol, Landscape Res Nat Conserv 10, 17-22 